\title{
Relationships Between the Attributes Virtual Business and Factors of Sustainable Value Creation in Enterprises in Poland
}

\author{
Prof. Bogusława Ziółkowska ${ }^{1}$
}

\begin{abstract}
The aim of the research was to find answers to the following question: It is the implementation of modern IT solutions supports the potential for sustainable development of enterprises? The article presents the results of research carried out in enterprises in Poland. The study involved 346 enterprises, including 143 micro, 104 small, 51 medium and 48 large. Among the surveyed enterprises predominated service companies (more than $2 / 3$ of the total number of participants in the study). Other company, representing $29.1 \%$ of the study population, have confirmed membership in the manufacturing sector.After the answers provided by the respondents were analyzed and compared to the virtualization levels in accordance with the Descriptive Model of Business Virtualization Levels designed by the author, it was concluded that virtualization is a significant tool to achieve an increase of values in all assessed fields, from the quality of relations with customer, through developing and maintaining good relations with suppliers and/or customers as far as resource configuration is concerned, to acquisition of knowledge and qualifications and sustainable development of enterprises.
\end{abstract}

Key Words: enterprise, strategy, level of virtualization, financial status, business values, resource configuration.

\section{Introduction}

At the very basis of defining category of balanced development, despite different interpretation of this term, there's always a necessity of connecting in development economic, ecologic and social aims alike. Kucęba (2015) According to E. Piontka (2002) balanced development is a solid development otherwise, which provides creating and upgrading a quality of life of modern and future generations through giving a proper shape of proportions between individual kinds of capital: economic, human and natural. Pearce and Turner (1990) claim, that solid development means maximizing of net benefits from economic development, at the same time protecting and providing renew of usefulness and quality of natural resources in a longs pan period. Economic development has to in that time stands not only for a growing per capita income, but also improvement of other elements of social prosperity. Grabowska (2010) It has to embrace necessary structural changes, both in economy and whole society. Therefore, making this kind of assumption enterprises are obliged to generate an added-value and share it with all inside and outside shareholders, as well as accumulate and invest it with an idea of next generations profits. Poskrobko (1997) differs sustainable development in ecological aspect as an activity limiting the pressure on natural environment and 
improving its condition through greening of economic processes and, in civilization aspect, as a process of searching, checking and involving new form of economic development - new technologies, new carriers of energy and social communication, as well as new, non-economic forms of social activities. Therefore, sustainable development is a process is progression, not a state. Wielgórka (2016) Appropriate run of every process requires control and coordinating various factors. In that matter we can assume, that implementing information and communication technologies to economic activity stands for leading factor of enterprises in gression on the way of sustainable development. Tomski (2015) Enterprises virtualization takes place both on the inside level, and in context of surrounding expectations. (Jelonek 2013) Hence, process of sustainable development has to be a process of choosing the way of development, consisting of loss minimization and maximization of benefits in area of virtualization - a process of optimization.

\section{Research methodology}

To define virtualization level of studied enterprises and correlation, which takes place between a level of virtualization and its ability to create sustained added-value, five levels of enterprise virtualization have been established, which depend on used computer tools and aims of its usage in area of three virtualization carriers (vectors): virtual meetings (contacts with customers), virtual sourcing (assets configuration) and virtual experience (developing of knowledge). (Ziółkowska 2004). There was also included a proposition of areas of enterprises virtualization included in Brunelle's analytical model (Brunelle 2009), establishing relations of business, inner and strategical types. Characteristic of features belong to specific levels of virtualization, in terms of each from specific virtualization vectors, have been included in Descriptive Model of Enterprises Virtualization Levels. (Ziółkowska 2013).

Researches included 346 enterprises in Poland. From fulfilled questionnaires received from enterprises and included in research follow that the biggest group were micro enterprises (143) and small ones (104). Moreover, 48 big enterprises and 51 enterprises which declare themselves as middle ones, have joined to the research. Questionnare construction allowed gathering information allowing to define level of activities virtualization and processes accomplishing in enterprises and their relation with enterprises ability to generate a sustain added-value.

\section{Evaluation of contacts virtualization degree with customers.}

In tab. 1 we attached a structure of obtained answers from the question about dominating way to obtain and maintain contacts with customers. 
Table 1. Structure of answers about dominating way of obtaining and maintai contact with customers in enterprise activity.

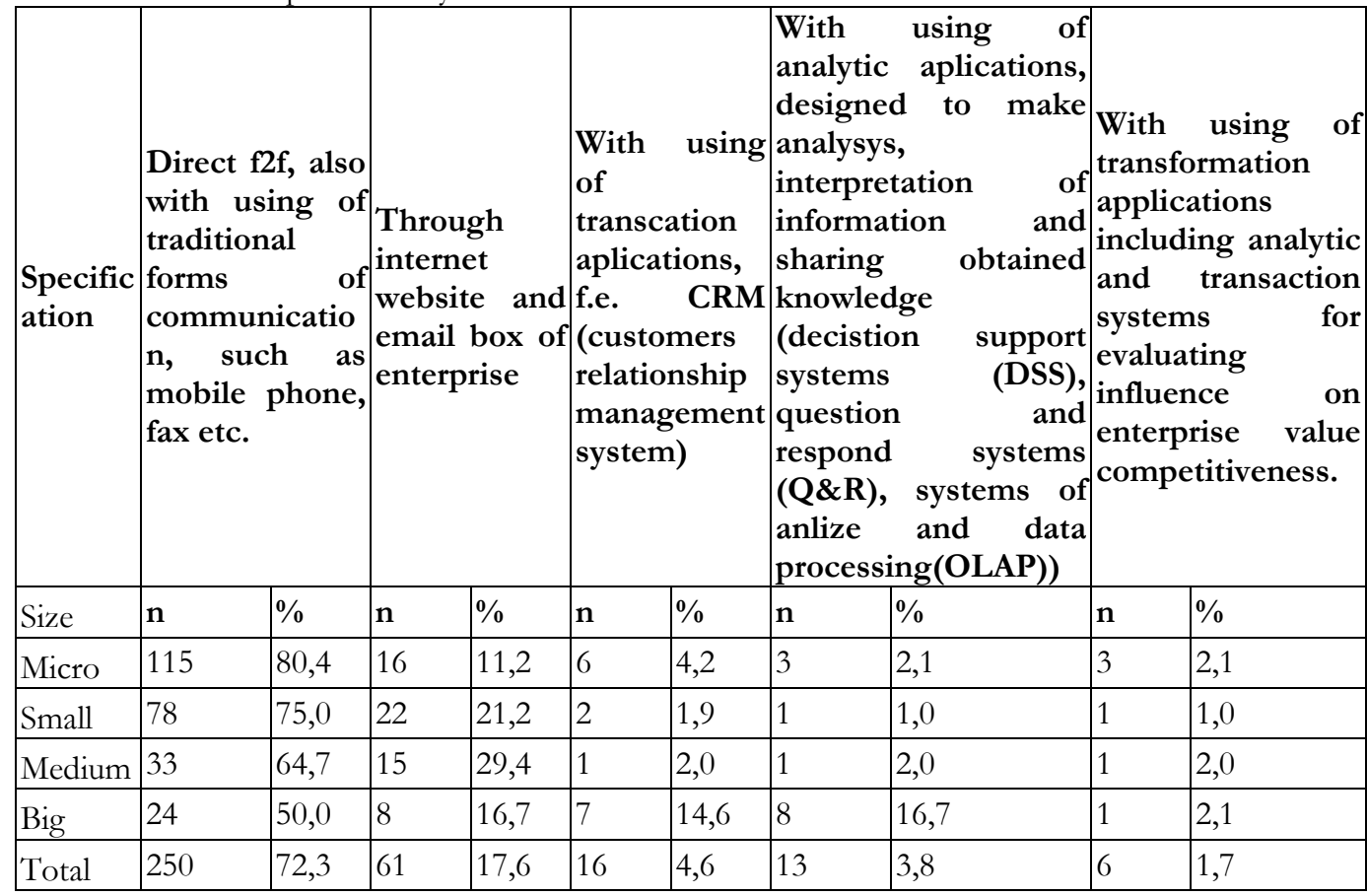

Source: Calculations of own.

Results of research point out that in relations of customers traditional forms of communication prevail ( $72,3 \%$ of all responds). Therefore, in terms of virtualization of contact with customers, almost $90 \%$ of all responds are either on first or on second degree from levels of virtualization in Descriptive Levels of Enterprises Virtualization Model. Third level of virtualization of contacts with customers have achieved slightly below one twenteeth (4,6\% of studied enterprises), fourth degree about 3,8\% and the highest, fifth level, characterized with using of transformation applications and realization of contacts with customers, was declared by $1.7 \%$ of enterprises participate in the study.

To evaluate the meaning of virtualization of contact with customers in sustain creating of value in studied enterprises, we asked about influence of information technologies on quality of relations with enterprises customers. Table 2. Shows the structure of gained answers. 
Table 2. Computer technologies influence on quality of contacts with customers.

\begin{tabular}{|c|c|c|c|c|c|c|c|c|c|c|}
\hline \multirow[t]{2}{*}{$\begin{array}{l}\text { Specific } \\
\text { ation }\end{array}$} & \multicolumn{2}{|c|}{$\begin{array}{l}\text { Does not } \\
\text { have } \\
\text { influance on } \\
\text { the way of } \\
\text { customers } \\
\text { service }\end{array}$} & \multicolumn{2}{|c|}{$\begin{array}{l}\text { Allowing } \\
\text { influence on } \\
\text { customers } \\
\text { mainly } \\
\text { through } \\
\text { giving } \\
\text { tchem } \\
\text { information } \\
\text { and } \\
\text { advertising } \\
\text { products or } \\
\text { services. }\end{array}$} & \multicolumn{2}{|c|}{$\begin{array}{l}\text { Customers } \\
\text { may use the } \\
\text { enterprise } \\
\text { offer at } \\
\text { distance, } \\
\text { make } \\
\text { orders, } \\
\text { make } \\
\text { reclamation } \\
\text { s, use after- } \\
\text { sales } \\
\text { service. }\end{array}$} & \multicolumn{2}{|c|}{ 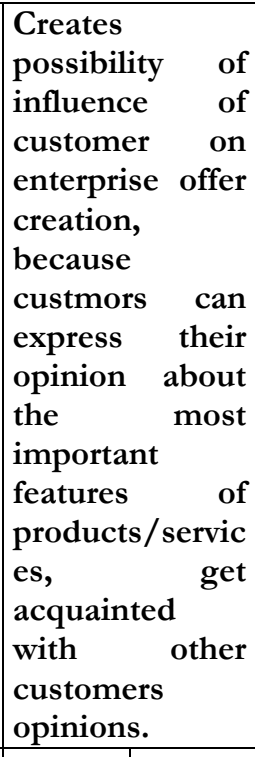 } & \multicolumn{2}{|c|}{$\begin{array}{lr}\text { Has a } & \text { crucial } \\
\text { meaning } & \text { in } \\
\text { adjustment } & \text { of } \\
\text { products/services } \\
\text { to real expectations } \\
\text { of customer (in } \\
\text { creating of added- } \\
\text { value for a } \\
\text { customer), because } \\
\text { it gives r an } \\
\text { opportunity r for } \\
\text { transformation, } \\
\text { information } \\
\text { gathered with use } \\
\text { of transaction } & \text { and } \\
\text { analytic } & \\
\text { applications. }\end{array}$} \\
\hline & $\mathrm{n}$ & $\%$ & $\mathrm{n}$ & $\%$ & $\mathbf{n}$ & $\%$ & $n$ & $\%$ & $n$ & $\%$ \\
\hline Micro & 71 & 49,3 & 34 & 20,0 & 20 & , & 9 & 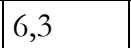 & 10 & , \\
\hline Sma & 37 & 35,6 & 34 & 32,7 & 11 & 10,6 & 12 & 11,5 & 10 & 9,6 \\
\hline Medium & 12 & 23,5 & 14 & 27,5 & 18 & 5,3 & 3 & 5,9 & 4 & 7,8 \\
\hline Big & 2 & 4,2 & 14 & 29,2 & 18 & Jו, & 10 & 12,5 & 8 & 16,7 \\
\hline Total & 122 & 35,2 & 96 & 27,7 & 67 & 19,3 & 30 & 8,6 & 32 & 9,2 \\
\hline
\end{tabular}

Source: Calculations of own.

According to analysis of answers structure given by respondents, 35,2\% of surveyed enterprises claimed, that computer technology does not have affect on customers service quality, 19,3\% of answers point out that thanks to computer technology customers may use the offer of enterprise at distance, make orders, make reclamations, use after-sales service, which meet their expectations in terms of achieve third level of virtualization in a Model proposed by author. Fourth level virtualization vector of contact with customer, corresponding with possibility of customer influence on creating offer of enterprise, expression of opinion about the most important features of products/services and know opinions of other customers thanks to using in enterprise computer technology had been declared as rewaring in $8,6 \%$ of surveyed enterprises. Whereas expectations of realization contact with customers on the highest available level, possible to proceed with actual IT advancement have been declared by $9,2 \%$ of surveyed enterprises.

Moreover, there was noted an explicit correlation between achieved level of contact with customers virtualization in enterprises and its ability to create added-value. (table 3) 
Table 3. Values of factor $\chi^{2}$ and $\varphi$ - Yule's for used computer technology in enterprises in the field of customer service and evaluate of their ability to create the sustain added-value.

\begin{tabular}{|l|l|l|l|}
\hline Problem & $\chi^{2}$ & $\mathbf{p}$ & $\varphi$ \\
\hline $\begin{array}{l}\text { Computer technology used in enterprise, in the field of } \\
\text { customer service, and evaluation of enterprise ability to } \\
\text { generate added-value. }\end{array}$ & $\mathbf{2 8 , 8 0 7 *}$ & 0,000 & 0,288 \\
\hline
\end{tabular}

Source: Calculations of own.

The higher level of contact with customers virtualization is related with higher evaluation of enterprise abilities to generate added-value and achieving sustainable development in a long span.

\section{Evaluation of virtualization level in the field of assets configuration.}

To perform evaluation of virtualization level in studied enterprises in the field of assets configuration posed the question about the way of gathering resources and what computer technologies have been used to achieve that. Structure of given answers have been placed in table 4 .

Table 4. Using of computer technologies in the field of assets configuration (structure))

\begin{tabular}{|c|c|c|c|c|c|c|c|c|c|c|}
\hline \multirow[t]{2}{*}{$\begin{array}{l}\text { Specificati } \\
\text { on } \\
\\
\text { Size }\end{array}$} & \multicolumn{2}{|c|}{$\begin{array}{l}\text { Only based } \\
\text { on } \\
\text { traditional } \\
\text { ways of } \\
\text { contacts } \\
\text { with } \\
\text { suppliers } \\
\text { (f2f, phone, } \\
\text { fax). }\end{array}$} & \multicolumn{2}{|c|}{$\begin{array}{l}\text { With using of } \\
\text { Internet } \\
\text { website and } \\
\text { email box. }\end{array}$} & \multicolumn{2}{|c|}{$\begin{array}{l}\text { Collaboration } \\
\text { with } \\
\text { suppliers } \\
\text { through } \\
\text { transaction } \\
\text { applications. }\end{array}$} & \multicolumn{2}{|c|}{$\begin{array}{l}\text { In } \\
\text { management } \\
\text { of human } \\
\text { resources } \\
\text { analytic } \\
\text { application } \\
\text { are in use, } \\
\text { f.e. Decision } \\
\text { Support } \\
\text { Systems (DI) }\end{array}$} & \multicolumn{2}{|c|}{$\begin{array}{l}\text { Usage of } \\
\text { transformation } \\
\text { applications } \\
\text { allows to } \\
\text { manage network } \\
\text { of connections } \\
\text { with suppliers, } \\
\text { gathering and } \\
\text { coordinating of } \\
\text { assets in the } \\
\text { most } \\
\text { economically } \\
\text { effective way. }\end{array}$} \\
\hline & $\mathbf{n}$ & $\%$ & n & $\%$ & n & $\%$ & n & $\%$ & $n$ & $\%$ \\
\hline Micro & 100 & 69,9 & 27 & 18,9 & 7 & 4,9 & 4 & 2,8 & 5 & 3,5 \\
\hline Small & 61 & 58,7 & 34 & 32,7 & 4 & 3,8 & 1 & 1,0 & 4 & 3,8 \\
\hline Medium & 17 & 33,3 & 21 & 41,2 & 4 & 7,8 & 2 & 3,9 & 7 & 13,7 \\
\hline Big & 11 & 22,9 & 14 & 29,2 & 5 & 10,4 & 7 & 14,6 & 11 & 22,9 \\
\hline Total & 189 & 54,6 & 96 & 27,7 & 20 & 5,8 & 14 & 4,0 & 27 & 7,8 \\
\hline
\end{tabular}

Source: Calculations of own

According to analysis structure of given answers, more than half of studied enterprises gathering their resources using only traditional forms of contact with suppliers $(54,6 \%)$. $27,7 \%$ of surveyed enterprises using e-mail to contact with suppliers and Internet 
website to present their offer. Results of research point out that over $80 \%$ of surveyed enterprises remain in the first or second assets virtualization level, mentioned by the author. Virtual sourcing on the fifth, highest level had been achieved in $1 / 5$ of big enterprises participating in research. Comparing to general amount of enterprises, it was less than $8 \%$.

To evaluate how virtual sourcing affects the enterprise's ability in the field of generating added-value and creating sustainable development factors, we investigated the correlation between level of virtualization of assets configuration in enterprises and its evaluation of ability to create added-value (tab. 5).

Table 5. Values of factos $\chi^{2}$ i $\varphi$ - Yule's for virtualization level of assets and ability to create sustainable added-value

\begin{tabular}{|l|l|l|l|}
\hline Problem & $\chi^{2}$ & $\mathbf{p}$ & $\varphi$ \\
\hline $\begin{array}{l}\text { Virtualization level of assets and ability to create } \\
\text { sustainable added-value }\end{array}$ & $\mathbf{2 6 , 9 8 3 *}$ & 0,001 & 0,279 \\
\hline
\end{tabular}

Source: Calculations of own.

Conducted research confirmed positive, important, statistical moderated dependency between assets configuration's virtualization level and evaluation of enterprises ability to create added-value. The higher level of technology and tools used to connect and implement contact with customers, the higther evaluation of enterprise's abilities to create added-value and ingress on the way of sustainable development.

\section{Evaluation of level of knowledge gaining.}

Results of conducted research pointed out that knowledge development in $3 / 4$ of surveyed enterprises takes place by gaining experiences by enterprise's employees $(59,7 \%$ of answers) and through stationary traineesips organized in enterprises for permanent employees (25,4\% of answers). Gaining knowledge through employing specialists from outside or new employees was pointed by $6,9 \%$ of total amount of enterprises, the same as buying know-how and licences is the way of gaining knowledge for $6.1 \%$ of surveyed enterprises (tab. 6.).

Table 6. Knowledge development in enterprise.

\begin{tabular}{|c|c|c|c|c|c|c|c|c|c|c|}
\hline \multirow{2}{*}{\begin{tabular}{|l} 
Specificati \\
on \\
Size
\end{tabular}} & \multicolumn{2}{|c|}{$\begin{array}{l}\text { Takes place } \\
\text { on the way of } \\
\text { gaining } \\
\text { employees } \\
\text { experiences. }\end{array}$} & \multicolumn{2}{|c|}{$\begin{array}{l}\text { As a result of } \\
\text { gaining new } \\
\text { employees } \\
\text { and } \\
\text { employing } \\
\text { outside } \\
\text { specialists. }\end{array}$} & \multicolumn{2}{|c|}{$\begin{array}{l}\text { Through } \\
\text { stationary } \\
\text { traineeships } \\
\text { organized for } \\
\text { permanent } \\
\text { employees. }\end{array}$} & \multicolumn{2}{|c|}{$\begin{array}{l}\text { In a way of } \\
\text { buying know- } \\
\text { how and } \\
\text { licenses. }\end{array}$} & \multicolumn{2}{|c|}{$\begin{array}{l}\text { Thanks to } \\
\text { usage of e- } \\
\text { learning. }\end{array}$} \\
\hline & $\mathrm{n}$ & $\%$ & $\mathrm{n}$ & $\%$ & $\mathrm{n}$ & $\%$ & $n$ & $\%$ & $\mathrm{n}$ & $\%$ \\
\hline Micro & 102 & 70,8 & 12 & 8,3 & 24 & 16,7 & 4 & 2,8 & 2 & 1,4 \\
\hline Small & 64 & 61,5 & 6 & 5,8 & 25 & 24,0 & 7 & 6,7 & 2 & 1,9 \\
\hline Medium & 28 & 54,9 & 5 & 9,8 & 16 & 31,4 & 2 & 3,9 & 0 & 0,0 \\
\hline
\end{tabular}




\begin{tabular}{|l|l|l|l|l|l|l|l|l|l|l|} 
Big & 13 & 27,1 & 1 & 2,1 & 23 & 47,9 & 8 & 16,7 & 3 & 6,3 \\
\hline Total & 207 & 59,7 & 24 & 6,9 & 88 & 25,4 & 21 & 6,1 & 7 & 2,0 \\
\hline
\end{tabular}

Source: Calculations of own.

Approach to the knowledge and competencies in enterprise has an influence on enterprise abilities evaluation to create sustainable added-value. $\quad\left(\chi^{2}=23,986 ; \quad p=0,002\right.$; $\varphi=0,263)-$ table 7.

Table 7. Values of factors $\chi^{2}$ i $\varphi$ - Yule's in approach to knowledge and competences and evaluation of ability to create sustainable added-value.

\begin{tabular}{|l|l|l|l|}
\hline Problem & $\chi^{2}$ & $\mathbf{p}$ & $\varphi$ \\
\hline $\begin{array}{l}\text { Knowledge and competences in enterprise and its ability to } \\
\text { create added-value. }\end{array}$ & $\mathbf{2 3 , 9 8 6 *}$ & 0,002 & 0,263 \\
\hline
\end{tabular}

Source: Calculations of own

The slightest percentage of indications in the field of method of knowledge gaining concern use of e-learing (just $2 \%$ ). Therefore, researched virtualization vectors population of surveyed enterprises in the field of knowledge development stay on considerably lower level of virtualization, than it could be achieved thanks to implementation of modern computer technologies in the field of knowledge management. Surveyed enterprises appreciate the role and meaning of virtual experience in cooperation network with other enterprises and achieving development in area of entering on the path leading to sustainable development, although especially in case of micro and small enterprises, we can find a technological obstacle for development of this kind.

\section{Summary}

As a result of the analyses mentioned above, the importance of value determinants for management of the enterprises included in the study and shaping of their strategy was defined; additionally, the level of virtualization of actions and processes applicable in the target enterprises and a link between these actions and financial status of the enterprise was diagnosed. After the answers provided by the respondents were analyzed and compared to the virtualization levels in accordance with the Descriptive Model of Business Virtualization Levels designed by the author, it was concluded that virtualization is a significant tool to achieve an increase of values in all assessed fields, from the quality of relations with customer, through developing and maintaining good relations with suppliers and/or customers as far as resource configuration is concerned, to acquisition of knowledge and qualifications and extension thereof inside the corporate structures.

\section{References}

Brunelle E. (2009), Do Virtual Enterprises Exist? A Proposed Analysis Model, „International Journal of eBusiness Management", vol. 3, no. 2. 
Grabowska M. (2010), Analysis of the Role of Working Capital and Cash Flow in Management of Limited Liability Companies, /In:/ Modern Company Management, (Ed.) Otola I., Wydawnictwo Wydziału Zarządzania Politechniki Częstochowskiej, Częstochowa, pp. 40-51

Jelonek D.,(2013) Wirtualizacja otoczenia organizacji. Kontekst niepewności decyzyjnej, /In:/ Zarzadzanie organizacja w warunkach niepewności - teoria $i$ praktyka (Ed.) Strzelecka A., Sekcja Wydawnictw Wydziału Zarządzania Politechniki Częstochowskiej, Częstochowa

Kucęba R. (2015), Changes in Management Processes and IT Technology Development - "Milestones", /In:/ Considerations About the Economy... (Ed.) Niedziółka D., Warsaw School of Economics Press, Warszawa, pp. 179-201

Pearce D., Turner R. K. (1990), Economics of Natural Resources and the Environment, JHU Press

Piontek B. (2002), Rozwój zrónnoważony i trwaly w miernikach oraz w systemach sprawozdawczości, Wydawnictwo: Wyższa Szkoła Ekonomii i Administracji w Bytomiu, Bytom

Poskrobko B. (1997), Teoretycz̨ne aspekty ekorožwoju, Ekonomia i Środowisko, 1(10), 7

Tomski P. (2015), Information Technology and Firm Internationalization, "Applied Mechanics and Materials", Vol.795, pp. 227-234

Wielgórka D. (2016), Environmental Management in the Aspect of Sustainable Development in Micro-, Small-, and Medium-Sized Enterprises, "Desalination and Water Treatmen" Vol.57, Iss.3, pp. $982-992$

Ziółkowska B. (2004), Ksztattowanie strategii organizacji wirtualnej, [n:] Zarzadzanie przeedsiębiorstwem w warunkach integracij europejskiej, Część 1, Zmiany w teorii i praktyce zarzadz̧ania, (Ed.). Podobiński A., Uczelniane Wydawnictwo Naukowo-Dydaktyczne AGH, Kraków, p. 393

Ziółkowska B.(2013), Zarzadzanie procesami tworzenia wartości w pržedsiębiorstwie, Perspektywa wirtualizacji, Wydawnictwo Politechniki Częstochowskiej, Częstochowa, ss. 183-186 